\title{
ECOMORPHOLOGICAL EVALUATION OF THE ŁYNA RIVER ALONG THE KOTOWO-ARDAPY SECTION
}

\author{
MirosŁaw GrZybowSKi \& ZBIGNIEW ENDLER \\ University of Warmia and Mazury in Olsztyn, Chair of Applied Ecology, Olsztyn, Poland
}

Manuscript received: December 30, 2011

Revised version: March 5, 2012

\begin{abstract}
GrZYbowsKi M. \& EndLer Z., Ecomorphological evaluation of the Łyna River along the Kotowo-Ardapy section. Quaestiones Geographicae 31(1), Bogucki Wydawnictwo Naukowe, Poznań 2012, pp. 51-65. 2 Figs., 6 Tabs. DOI 10.2478/v10117-012-0008-6, ISSN 0137-477X.
\end{abstract}

AвSTRACT. The Water Framework Directive of the European Parliament and the European Union Council No 2000/60/EC, of 23rd October 2000, on the common water policy, modifies provisional rules of river monitoring. Being an EU country, Poland has been obliged to introduce the new regulations and, additionally, to elaborate and implement regional methods for hydromorphological assessment of quality of river water no later than 2006. In the present study, hydromorphological evaluation of the Eyna River along a 7-km-long section between Kortowo and Adrapy has been completed. Along this section, the Łyna is a lowland, gravel and highly natural river. Two methods of evaluation, based on different assumptions, were applied. One is a British method, called River Habitat Survey (RHS), whereas the other one is based on German methods, known as ecomorphological river evaluation, and has been developed by Ilnicki (University of Agriculture in Poznań). A comparative analysis of the usefulness of both methods was performed, based on the results obtained with each method. The scope of our study has been to include a survey of the flora, phytosociological relationships and fauna of the river and its environs. Both methods implied that the river was more natural upstream and the results are shown on maps. The ecomorphological river evaluation, according to Ilnicki, assesses the river along its entire course, which is in accord with the Directive's assumptions. In contrast, the RHS method, which analyses selected, 500-meter-long sections, results in a non-continuous river evaluation. I our study, the assessment by RHS led to the omission of the most valuable section of the river. However, RHS (owing to the HQA index) more accurately indicates anthropogenic influences on the river, unlike the ecomorphological evaluation by Ilnicki, which lacks such an index. Consequently, the estimation of the degree of naturalness or extent of man-made pressure is not free from some subjectivity, which means that the surveyor needs certain experience. The RHS method is objective and unambiguous but still needs adaptation to the Polish conditions. Both methods can be statistically elaborated. At present, it is difficult to compare the reliability of the results obtained by both methods. The RHS method requires an application of a reference group of rivers, which has not been prepared for Poland yet. Assuming that the RHS database on the examined rivers (the Department of Ecology and Environmental Protection, August Cieszkowski Agricultural University in Poznań) could correspond to that missing reference group for Polish rivers, the results obtained by both methods were comparable.

KEY wORDS: hydromorphologiccal evaluation of rivers, ecological condition, the Water Framework Directive

Mirostaw Grzybowski, Zbigniew Endler, Chair of Applied Ecology, University of Warmia and Mazury in Olsztyn, ul.Oczapowskiego 5,10-957 Olsztyn, Poland, e-mail: grzybomi@uwm.edu.pl,wesba@uwm.edu.pl 


\section{Introduction}

The Water Framework Directive (WFD) No 2000/60/EC of the European Parliament and the European Union Coucil, of $23^{\text {rd }}$ October 2000, on the common water policy, modifies the previous regulations concerning river monitoring. The dominant group of methods for evaluation of water quality comprises biological techniques, while the physicochemical and hydromorpho-

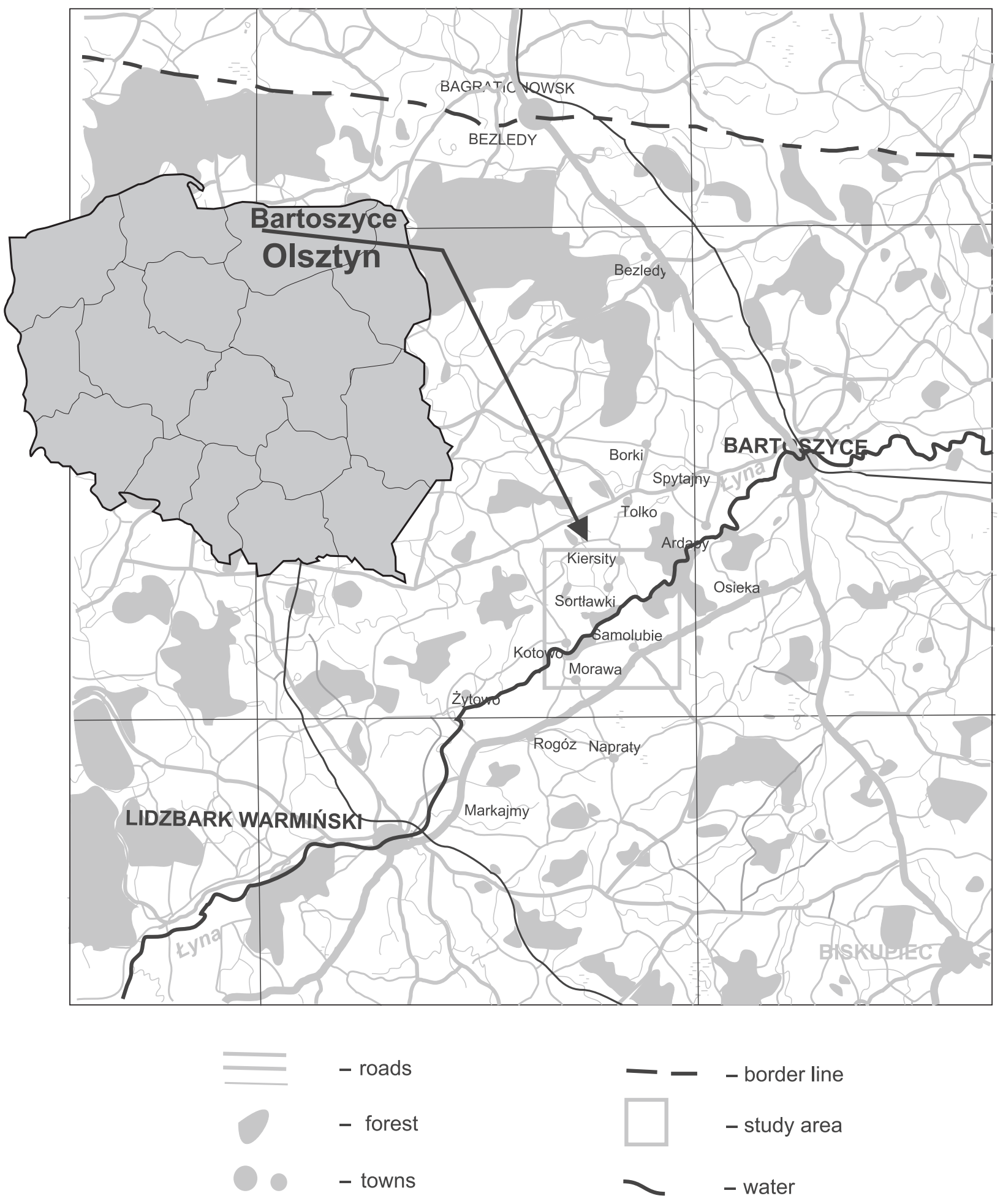

Fig. 1. The localization of the studied area. 
logical monitoring serves an auxiliary role. The new rules also deal with specific and non-specific contaminations (Monitoring Guidance ... 2003). Being an EU country, Poland is implementing the WFD rules and, in compliance with the imposed schedule, is expected to elaborate and implement its own hydromorphological methodology for evaluation of river quality no later than 2006.

In Europe, two approaches to the hydromorphological evaluation of rivers dominate. One is represented by methods originating from the Germanspeaking circle: the LAWA method for small and large rivers; the LAWA review method, a method elaborated in Mecklenburg, which is based on evaluation of aerial photographs (Ilnicki \& Górecki 2005). The other approach is represented by the British RHS (River Habitat Survey) method (Raven et al. 1998). The French SEQ method (Agences de l'Eau and Ministère de l'Environnement 1998) is also gaining recognition. Both the German and the French methods assume that a river is a continuum.

Outside Europe, the hydromorphological evaluation of the quality of rivers is likewise an important element of the evaluation of lotic waters. In the USA, the US Environmental Protection Agency uses the HABSCORE method for the hydromorphological evaluation of rivers (Platts 1983, Plafkin et al. 1998). In Australia, analogous methodology, based on the existing, mainly Anglo-Saxon, American and European methodologies, was designed in the 1990s (Anderson 1993). In the early $21^{\text {st }}$ century, regular reports began to be published on the studies conducted in Australia (Norris et al. 2001, Parson et al. 2002).

A Polish concept for the hydromorphological evaluation of rivers was approved of by the Technical Committee of the Ministry for the Environment in 2005 (Ilnicki \& Górecki 2005) and soon the work on an original Polish method for the hydromorphological evaluation of rivers MHR shall be completed (Ilnicki et al. 2009a, 2009b, 2010a, $2010 \mathrm{~b}$ ). This paper voices the authors' opinion in the ongoing discussion and its aim is to compare two methods for the hydromorphological evaluation of rivers.

\section{Methods}

All field tests were performed from April to October 2005. The hydromorphological evaluation was preceded by making a nature inventory. Particular attention was paid to the flora as plants are among the major elements shaping ecosystems and landscapes; they also create habitats for animals. At the same time, flora creates a complex image reflecting habitat conditions and is a sensitive indicator of any environmental changes. Plants are therefore a synthetic expression of the dynamics and modifications in a given environment (Matuszkiewicz 1974). In 2005, throughout the whole plant growing season (from early spring to late autumn), floristic, phytosociological and faunistic field tests were conducted. The present state of the vegetation cover was characterised according to our analysis of the collected plant material. Specification of the flora was based on the floral lists obtained by the route method (Falinski 1990). For rare and protected plant species, their location was recorded in the form of a topogram (Fig. 2). For the purpose of this paper, an inventory of the flora of vascular plants was made and presented synthetically in tables.

The elaboration of the plant cover was based on cartographic work, which enabled us to prepare a plant map according to geobotanic cartography (Faliński 1990). The map shows plant assemblages found within 50 meters of the river banks.

\section{The hydromorphological evaluation}

Two methods were selected for the hydromorphological evaluation: the ecomorphological evaluation of watercourses according to Ilnicki (Ilnicki \& Lewandowski 1996), resulting from an analysis of 23 'continental' methodologies, and the British one called River Habitat Survey (RHS) (Environment Agency 2003). 


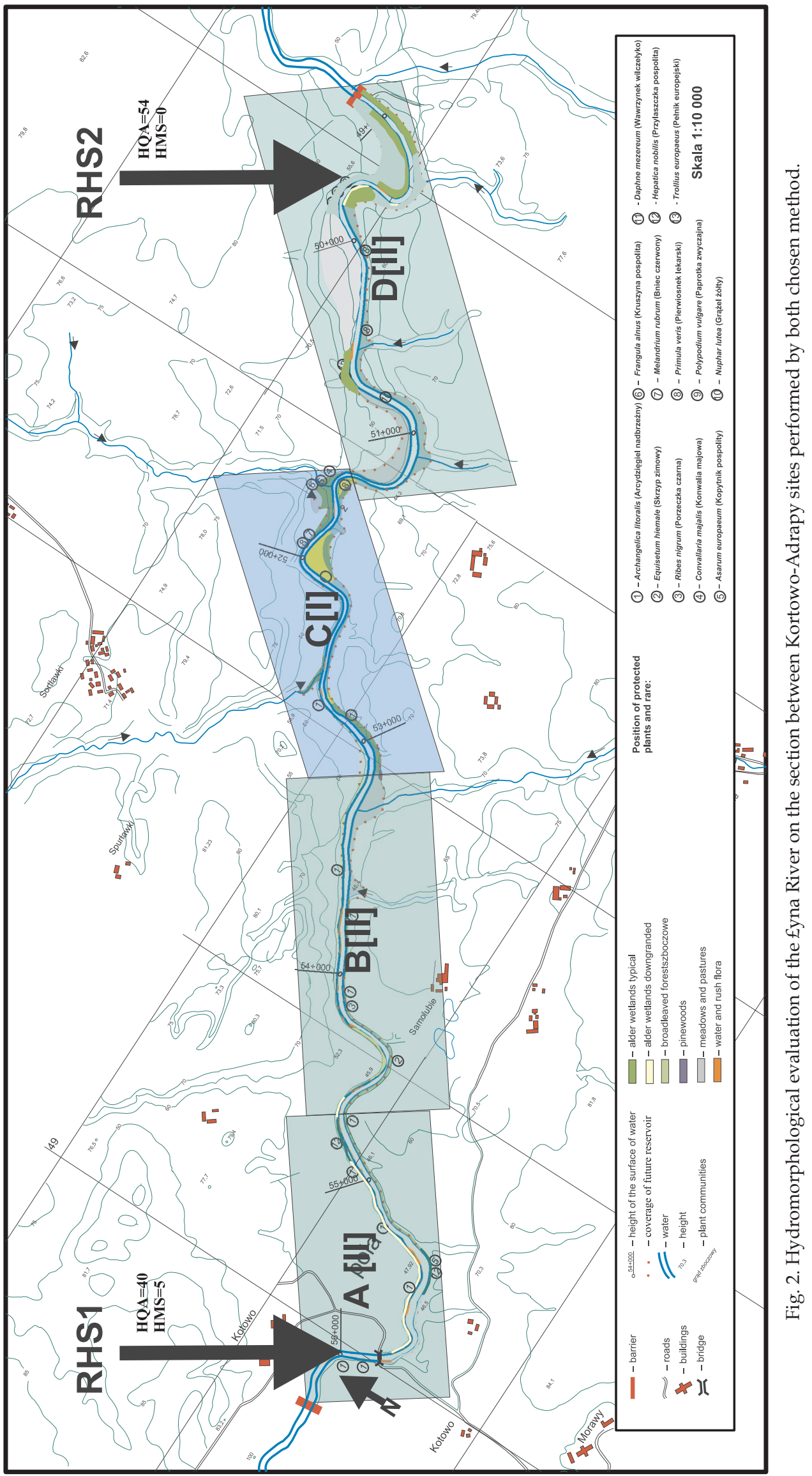




\subsection{The ecohydromorphological evaluation (Ilnicki, Lewandowski 1997)}

The ecomorphological evaluation assumes that it will cover the whole length of a watercourse, which conforms with the WFD. The analysed section of the Łyna River had been arbitrarily divided into 4 segments: A, B, C and D. The ecomorphological evaluation according to Ilnicki comprises two stages:

- stage one consists of making an inventory of the analysed section of a watercourse according to field protocols, one of which characterises parameters of the water and river bank ecosystems and the other one pertains to parameters of the river shore zone, plant assemblages and the river valley;

- stage two is an ecomorphological evaluation based on eight parameters:

- morphology of the river channel (route, embankments, the longitudinal and crosssection, depth, the bottom substrate, the slope and shape of banks, the scope of river regulation works and engineering methods applied to this end, the existing water engineering constructions and technical reinforcements);

- hydrology of the watercourse (the volume and changeability of water flow, water state in the channel, water depth, width of the water table)

- physicochemical properties of the water (degree of eutrophication, mineral and organic pollutants)

- trees growing on the river banks (density of tree stands, species, age, breast height of trees, water shading)
- water plants and river embankment plants (plant assemblages, plant cover area, indicator plants)

- the shoreline zone (presence, width, type of land-use)

- land-use in the river valley (type of landuse and respective surface area)

- particular natural assets of the valley (existing and expected area of nature conservation - for valleys of large rivers)

These parameters are evaluated on five-degree and five-score scales, except the plants and natural assets (three degrees).

The general ecological and landscape assets of the investigated area were assessed by computing an arithmetic mean and treating all the parameters as equal, according to Table 1.

\subsection{River Habitat Survey (RHS) (Environment Agency 2003)}

River Habitat Survey is performed on a selected, representative 500-meter long section of a river. In Great Britain, the land surface has been divided into $10 \times 10 \mathrm{~km}$ squares and typically 3 to 4 sections per square are selected for RHS. For the purpose of this paper, two RHS sections were selected along the seven-kilometre segment of the analysed river. RHS1 was within segment A and RHS2 was within segment D of the ecomorphological evaluation.

RHS involves completion of a four-page survey form, which is divided into numbered sections from A to P. The survey comprises two aspects:

Table 1. Descriptors of the category of water course naturalness (Ilnicki \& Lewandowski 1997).

\begin{tabular}{|c|c|c|}
\hline $\begin{array}{l}\text { Category of } \\
\text { naturalness }\end{array}$ & Descriptors & $\begin{array}{l}\text { Arithmetic mean } \\
\text { of the score }\end{array}$ \\
\hline I & $\begin{array}{l}\text { Most valuable for ecology and landscape, semi-natural watercourses, hardly } \\
\text { modified river valley which deserve conservation }\end{array}$ & $>4.25$ \\
\hline II & $\begin{array}{l}\text { Valuable for ecology, semi-natural watercourses, relatively not much modified } \\
\text { river valleys }\end{array}$ & $3.50-4.24$ \\
\hline III & $\begin{array}{l}\text { Moderately valuable for ecology and landscape watercourses, some } \\
\text { sections regulated. }\end{array}$ & $2.75-3.49$ \\
\hline IV & $\begin{array}{c}\text { Watercourses of evidently modified ecosystem, of little value to landscape, com- } \\
\text { pletely regulated }\end{array}$ & $2.00-2.74$ \\
\hline V & $\begin{array}{l}\text { Watercourses completely regulated with embankments made from artificial ele- } \\
\text { ments, artificially dug canals, strongly drained valleys }\end{array}$ & $<1.99$ \\
\hline
\end{tabular}


- one including 10 research profiles, $50 \mathrm{~m}$ distant from one another, in which the following are evaluated:

- E - physical attributes of the river banks and channel (the width of a profile is $1 \mathrm{~m}$ ) (bottom and shore sediments, modification, morphological features, type of flow)

- F - land-use and structure of plant cover on the river banks and the nearest area (within $5 \mathrm{~m}$ of the river) (width of a profile $10 \mathrm{~m}$ )

- G - type of plants in the channel (width of a profile $10 \mathrm{~m}$ )

- the other one pertaining to the whole 500-meter segment of a river, in a synthetic approach, where the following parameters are examined:

- A - field survey details

- B - predominant form of the river valley

- C - number of riffles, pools and point bars

- D - water engineering objects

- H - land-use within 50 meters of the banktops

- I - bank profiles

- J - extent of trees and associated features

- K - extent of the channel and bank features

- L - dimensions of the channel (measured at one representative site)

- M - interesting features (braided channel, tributaries, amphiphytes, catchment basin use, etc.)

- N - choked channel

- O - observed nuisance plant species

- P - overall characteristics (man-made pressures, fauna, other characteristics)

Once completed, the survey serves to calculate the Habitat Modification Score (HMS) and Habitat Quality Assessment Score (HQA).

The HMS defines the extent of modifications in the morphology of the watercourse caused by the number and types of water engineering constructions, reinforcements and changes to the river profile.

The HQA evaluates the presence and diversity of natural components of the river's channel and valley, such as the physical characteristics of the channel and shores, the structure of the plant cover on the banks, the type of plants in the channel, land-use within $50 \mathrm{~m}$ of the banks, trees and other characteristics typical of the natural character of a river.

Afterwards, based on the reference group of rivers, the quality of a giver watercourse is evaluated.

\section{Description of the investigated area}

Administratively, the Kotowo-Ardapy section of the Łyna River lies in the north-western part of the Province of Warmia and Mazury, in the communes of Bartoszyce, Lidzbark Warmiński and Kiwity (Fig. 1). The valley of the Łyna along the analysed length of the river, with respect to nature conservation, is of local importance. It has some environmental value, mainly as a landscape component in this area. It lies within the Landscape Conservation Area called the Valley of the Łyna River (Journal of Law of the Province of Warmia and Mazury 03.52.725). Locally, it is the best preserved nature object, whose environmental and landscape-related assets contrast with the heavily modified surrounding agricultural landscape.

According to the typology worked out under the Water Framework Directive No 2000/60/EC of the European Parliament and the European Union Council of $23^{\text {rd }}$ October 2003 on the common water policy, the Łyna can be classified as:

- a lowland river [the altitude typology $<200 \mathrm{~m}$ above mean sea level]

- medium-sized [the size of the catchment 1,000 $\left.-10,000 \mathrm{~km}^{2}\right]$

- silicate substrate [geology]

According to the abiotic ty pology of rivers and streams in Poland, the Łyna is a lowland, gravel river (Błachuta 2005).

According to Illies (1978), the Łyna River belongs to ecoregion XVI called the Eastern Plains, except its lower section outside the Polish borders, which flows through ecoregion XV named the Baltic Region.

Under the physiogeographical division of Poland (Kondracki 2002), this area belongs to:

- the megaregion [8] - the East European Lowland

- the province [84] - the East Baltic and Byelorussian Lowlands 
- the subprovince [841] - the East Baltic Coastland

- the macroregion [841.5] - the Old Prussian Lowland

the mesoregion [841.59] - the Sępopol Plain

The Sępopol Plain is a vast basin, raising up to $80-100 \mathrm{~m}$ AMSL at the edges and depressing towards its centre to $40-50 \mathrm{~m}$ AMSL. The average height above mean sea level of the analysed section of the river is $46 \mathrm{~m}$, which means that it flows through the lowest part of the region. The whole area of the plain is cut downwards to $20-30 \mathrm{~m}$ by two valleys of the rivers: the Łyna and the Guber, which flows into the Łyna near Sepopol. The lowland landscape - rather even and monotonous becomes more diverse owing to the river valleys. Along the analysed section, the Łyna River cuts into moraine formations, creating a deep and narrow valley with sporadically high banks. The river strongly meanders and its erosive force is seen clearly as it shapes concave cliffs where the river bends. The nearby landscape relief is diversified by small valleys of streams flowing perpendicularly to the river as well as small gorges and ravines, periodically filled with water by watercourses which dry up in summer. In spring, frequent seepages of ferruginous subsoil water are observed.

The surface of the plain is covered by the Quaternary formations, originating from the last period of the Baltic glaciation, called the Pomeranian stage. Most of it consists of ground moraine material. There are no forms created by the marginal action of the glacier. In some places, there are layers of red clay, which had been deposited in short-lived lakes created in front of the receding Scandinavian Glacier. Some of the clay turned into clayey silt or sand, up to 2 meters in depth. Above these formations, heavy brown soils were produced (Kondracki 2002).

According to the geobotanical division into regions (Matuszkiewicz 1993), the area belongs to:

- the Central European Province

- the South Baltic Subprovince

- the Pomeranian Division

- the East Pomeranian Region

- the Old Prussian Subregion

The average temperature in the Old Prussian Subregion is $7.3^{\circ} \mathrm{C}$, with the lowest recorded temperature being $-29.8^{\circ} \mathrm{C}$ and the number of days with the temperature above $0^{\circ} \mathrm{C}$ up to 282; the average duration of thermal winter is 82 days; the average number of days with snow cover is 70; on average, the temperature drops below $-10^{\circ} \mathrm{C}$ on 17 days a year; the average annual precipitation from 1951 to 1970 was $660 \mathrm{~mm}$, with the highest rainfall recorded in summer (Matuszkiewicz 2001). This is one of the coldest and rainiest regions in Poland. It is characterised by a large number of boreal and arctic plant species as well as plant communities often classified as post-glacial relics.

\section{Results}

\subsection{Environmental evaluation}

A large diversity of the habitats in the analysed area favours a great wealth of the local flora. Although the floristic inventory made for this study was incomplete, 302 species of vascular plants representing 67 families were recorded (Table 2). The authors estimate that the full list of the vascular flora in this area could contain over 400 species. These are mainly species typical of wet riparian forests, mesophilic deciduous forests (dry-ground forests) and meadows. There are also less numerous plants representing water, segetal, ruderal and water-head species.

Among the recorded taxa, ten are listed as legally protected ones (Journal of Law of $28^{\text {th }}$ July 2004, No 168, item 1764) and three are rare ones (Zarzycki et al. 1992). They are represented by the following species: cowslip (Primula oficinalis), adder fern (Polypodium vulgare), white ginger (Asarum europaeum), hepatica (Hepatica nobilis), black currant (Ribes nigrum), alder buckthorn (Rhamnus frangula), mezereon (Daphne mezereum), yellow waterlily (Nuphar lutea), lily of the valley (Convallaria majalis), rough horsetail (Equisetum hyemale), red campion (Melandrium rubrum) and angelica (Archangelica litoralis). Noteworthy is a stand of globe flower (Trollius europaeus), which grows on the bank of the Łyna River in the upper part of the analysed section, on alluvial deposits (Fig. 2). Stands of this plant, considered a very ornamental one, are disappearing all over Poland. Unfortunately, with only one clump of this plant noticed in our study, this stand is not likely to 
Table 2. Vascular Plants families recorded in the Łyna River within the section between Kortowo-Adrapy sites.

\begin{tabular}{|c|c|}
\hline Family & Number of species \\
\hline Poaceae (Gramineae) - Grasses, Asteraceae (Compositae) - Aster & 35 species each \\
\hline Fabaceae (Papilionaceae) - Papilionaceus & 18 species \\
\hline Rosaceae - Rose & 17 species \\
\hline Lamiaceae (Labiatae) - Mint & 13 species \\
\hline $\begin{array}{c}\text { Caryophyllaceae - Carnation, Ranunculaceae - Buttercup } \\
\text { Brassicaceae (Cruciferae) - Crucifers }\end{array}$ & 12 species each \\
\hline Salicaceae - Willow & 9 species \\
\hline Polygonaceae - Knotweed & 8 species \\
\hline Apiaceae (Umbelliferae) - Carrot, Cyperaceae - Sedge & 7 species each \\
\hline Scrophulariaceae - Figwort & 6 species \\
\hline Onagraceae (Oenotheraceae) - Willowherb & 5 species \\
\hline $\begin{array}{c}\text { Geraniaceae - Cranesbill, Betulaceae - Birch, Campanulaceae - Bellflower, Violaceae - Violet, } \\
\text { Liliaceae - Lily, Rubiaceae - Madder, Polypodiaceae -Fern, Potamogetonaceae - Potamogeton, } \\
\text { Juncaceae - Rush, Equisetaceae - Horsetail }\end{array}$ & 4 species each \\
\hline Plantaginacea - Plantain, Primulaceae - Primrose, Lemnaceae - Duckweed, Pinaceae - Pine & 3 species each \\
\hline $\begin{array}{c}\text { Fagaceae - Beech, Celastraceae - Staff vine (Bittersweet), Fumariaceae -Fumitory, Acer- } \\
\text { aceae - Maple, Papaveraceae - Poppy, Balsaminaceae - Balsam, Oleaceae - Olive, Urticaceae } \\
\text { - Nettle, Convonvulaceae - Bindweed, Caprifoliaceae - Honeysuckle, Solanaceae - Potato, } \\
\text { Boraginaceae - Borage, - Alismataceae, Hydrocharitaceae - Water-plantain }\end{array}$ & 2 species each \\
\hline $\begin{array}{c}\text { Grossulariaceae - Ribes, Cornaceae - Dogwood, Hypericaceae (Guttiferea) - St John's wort, } \\
\text { Loranthaceae - Mistletoe, Crassulaceae - Orpine, Nymphaeaceae - Water lily, Aristolochoiace- } \\
\text { ae - Birthwort, Chenopodiaceae - Goosefoot, Cannabaceae - Hemp, Iridaceae - Iris, Valeri- } \\
\text { anaceae - Valerian, Corylaceae - Hazel, Tiliaceae - Linden, Butomaceae - Flowering rush, } \\
\text { Adoxaceae - Muskroot, Lentibulariaceae - Bladderwort, Rhamnaceae - Buckthorn, Oxalidace- } \\
\text { ae - Wood sorel, Dipsacaceae - Teasel, Saxifragaceae - Saxifrage, Thymelaeaceae - Daphne, } \\
\text { Ulmaceae - Elm, Euphorbiaceae - Spruge, Ericaceae - Heath }\end{array}$ & 1 species each \\
\hline In total: & 302 \\
\hline
\end{tabular}

survive. Stands of 13 rare and protected species are illustrated in Fig. 2.

For ecologists, the most important plant communities in this area are woodlands. They are represented by riparian, wet leafy, dry-ground, substitute with pine trees in mixed fresh coniferous and poor dry-ground forest habitats and initial (greenwoods and forest plantations) forests.

Among the non-forest phytocenoses, there are synanthropic habitats (fields, fallow land, land around homesteads) as well as meadows and pastures, rushes, water habitats and thickets.

The localisation of plant assemblages is shown in Fig. 2.

Riparian assemblages belong to azonal plants, i.e. not connected with any particular plant zone. These communities are associated with habitats in which surface waters are the most important factor shaping the whole habitat. In our study, they occur in immediate proximity to the river or its tributary streams, as remnants on the inundation terrace of the river valley, along nearly all the length of this section of the Łyna (Fig. 2).
Apart from typical highly natural forms, they are often heavily modified communities with a disturbed storey structure, serving the function of an ecotone between the river and inland habitats, mainly meadows, dry-ground forests, ruderal habitats and tilled fields. A unique feature of the local dry-ground forests is the occurrence of giant, up to 3 meter tall, specimens of angelica (Archangelica litoralis) growing in the least shaded spots. The thick herbaceous vegetation inhibits any abundant growth of moss plants. Nonetheless, some species such as hart's tongue (Plagiomnium undulatum) and rough-stalk feather moss (Brachythecium rutabulum) are widespread. Specimens of angelica (Archangelica litoralis) were observed in both typical and degraded forms. Based on the moisture ratios in the analysed area, the following forms of dry-ground forests were distinguished: water logged, closest to the Łyna River, with bittercress (Cardamina amara), marsh marigold (Caltha palustris), moss (Plagiomnium affine), and frequent angelica (Archangelica litoralis), and a group of proper dry-ground forests, with 
enchanter's nightshade (Circaea lutetiana) and bird cherry (Padus avium) but no angelica (Archangelica litoralis).

The sub-Atlantic dry-ground forests (Stellario holosteae-Carpinetum betuli) found in this area are either multi-species deciduous forests of eutrophic habitats, poor in moisture, or fresh ones (alliance Carpinion betuli in the class QuercoFageta), growing on moist but not flooded brown or grey-podsolic soils formed on loamy or sandy and loamy soils. In the analysed area, they were often in close proximity of riparian forests or they directly descended to the river channel over steep cliffs (Fig. 2). The local dry-ground forests are valuable phytocenoses, on which the biodiversity of the whole area relies. The best preserved patches of such forests are where many rare and protected species of animals and plants dwell. Another important ecological function these forests perform is that they counteract the erosion on the steepest river banks.

Wet leafy forests are the rarest type of forest habitats in this area. However, a eutrophic wet leafy forest Ribeso nigri - Alenetum of the class Alnetea glutinosae, order Alnetalia glutinosae, with the protected species of black currant (Ribes nigrum) was recorded.

To the left side of the river, along the lower and middle section of its analysed course, there are greenwoods and forest plantations, which are dominated by less than ten-year-old planted woods of a mixed species composition (black alder, European larch, common oak, Norway spruce, Scotch pine and, added, maple, linden and beech). They were established on former tilled land and grassland. Over most of this afforested area, no structure or species composition typical of forest assemblages has been formed yet. The flora of these forest plantations is still dominated by the species of the former plant assemblages.

Although there are many assemblages of synanthropic plants in the analysed region, they cover small areas (Fig. 2). Thus, their environmental value or ecological role are small. Two main groups are distinguishable: ruderal assemblages and, less common, segetal assemblages. They are predominantly observed in areas under strong man-made pressure.
The existing small fragments of grasslands are dominated by assemblages of the alliance Cynosurion (class Molinio-Arrhenatheretea). The structurecreating species in these assemblages are mainly various species of grasses.

Thicket assemblages are rare in this region. They cover small areas, usually at the edges of a forest and fields, or a forest and pastures. They represent thermophilous Rubo fruticosi-Prunetum spinosae assemblages of the class Rhamno-Prunetea.

Marshland assemblages along the analysed river section do not play any significant role due to the steep river banks and lateral erosion, leading to absence of habitats suitable for the development of such plant communities. Two assemblages of this type were only recorded: soft rush (Juncentum effusi) and water mint (Mentha aquatica).

The most important factor conditioning the presence of rush and water plants in lotic waters is the water current, which shapes the spatial structure, plant species composition and their quantitative ratios in river phytocenoses.

In the analysed section of the Łyna River, both rush and water plants are scarce and grow only where the water current slows down or along the banks where the erosive force is weaker and the river's accumulative action prevails. Thus, such vegetation is irregularly distributed in the form of small patches, occurring where the river flow is slower. The distinguished assemblages of such plants are fragmentary and facial growth is rarely observed. Of the alliance Phragmition, only two plant assemblages were found. Phytocenoses of common reed (Phragmitetum communis) dominate with respect to covered surface. Assemblages of glyceria maxima (Glycerietum maximae) played a much less important role.

Of the alliance Magnocaricion of low rush, patches of swamp sedge (Caricetum acutiformis), canary grass (Phalaridetum arundinaceae) and yellow iris (Iretum pseudoacori) were found.

Floating-leaf plants were represented by only one phytocenosis of yellow nuphar NupharoNymphaeetum albae with the protected species of yellow nuphar (Nuphar lutea). Presence of just one patch in the middle section of the analysed fragment of the Łyna River was noticed. 
Submerged plants consisted of assemblages of fennel pondweed (Potamogeton pectinati) occurring sporadically along the whole cross-section of the river although avoiding the rapid current. Apart from the dominant species, i.e. fennel podnweed (Potamogeton pectinatus), there was also long-leaf pondweed (Potamogeton nodosus). Phytocenoses of clasping-leaf pondweed (Potamogetanetum perfoliati) appeared frequently, forming small communities.

In addition, presence of the association of arrowhead and unbranched bur-reed (SagittarioSparganietum emersi) was found, represented by a variant with the arrowhead possessing characteristic, tape-like leaves of junevile character. The pleuston was represented by three species, which did not create phytocenoses due to the rapid current.

Among the 20 species of ichthyofauna found in the analysed section of the river, 3 are fully protected species (brock lamprey, spirlin and miller's thumb) and 1 is a partly protected species (common loach). The dominant fish species were: roach, gudgeon, bleak, perch and spirlin. Chub, vimba and bream are captured in this river section quite frequently and in relatively large numbers (Terlecki et al. 2004).

Among herpetofauna, there were 4 species of amphibians and 2 species of reptiles, all protected ones, found in the examined area. The most common were European toad and moor frog (Grzybowski et al. 2005).

Avifauna was represented by 47 species of birds, of which 41 were nesting species, 2 - probably nesting ones and $4-$ passing. All the determined nesting species are under strict species protection (Journal of Law of $28^{\text {th }}$ September 2004, No 220, item 2237), except mallard. Among the domiant bird species were: chaffinch (30 couples), chiffchaff (21 couples), great titmouse (16 couples), wren (16 couples), blackbird (10 couples) and common starling (8 couples). This is an association of birds typical and widespread in tree assemblages. Among the birds closely associated with water bodies and waterlogged areas (water and mud habitats), the following species were found: mallard (4 couples), goosander (1 couple), green sandpiper (2 couples), common sandpiper ( 1 most probably nesting couple) and kingfisher (3 couples) (Grzybowski et al. 2005).
The theriofauna along the analysed section of the Łyna River comprised 8 species: bank vole (Clethrionomys glareolus), which had left marks of foraging on brambles in several spots on both sides of the river, European water rat (Arvicola terrestris) (under partial species protection), whose hills and footprints had been found in three spots on the right side of the river; otter (Lutra lutra) (under partial protection), one individual spotted a few times near the village Ardapy; ermine (Mustela erminea) (under strict species protection), one individual spotted once and footprints of an ermine found in two locations; Americal mink (Mustela vison) - left many traces and footprints on both sides of the river; wild boar (Sus scrofa); roe deer (Capreolus capreolus), beaver (Castor fiber) (under partial protection), with foraging sites of beavers found along the whole section of the river, in which most likely two beaver families dwell.

\subsection{Hydromorphological evaluation}

Along the analysed section of the Łyna River, the quality of water was tested twice according to the hydromorphological parameters.

The first evaluation was completed with the ecomorphological evaluation method (Ilnicki \& Lewandowski 1997).

Considering the criteria assessing the morphology of the river channel, it has been determined that the analysed section of the Łyna River is a non-regulated meandering watercourse, flowing along a highly varied route. The shores are varied and changeable, alternately flat or very steep, up to $20 \mathrm{~m}$ above the water table level. The cross-section, however, is hardly changeable, and the width of the water table is not varied, although it was given a score of 5 on the assumption that it was typical of medium-size rivers. Along the whole length, no technical facilities were found, except the first segment (A), where a three-pier bridge stood. In the same area, some influence of the nearby agricultural activity on the river valley was observed and consequently this part of the river scored 4.

The hydrology of all the analysed segments of the river was similar and scored 5 . The watercourse constantly carried water of the depth of 
more than 1 meter, but large variations in water table were seen and its width was over 15 meters along the whole length of the analysed river section.

The water quality tests completed by the State Inspectorate for Environmental Conservation in Olsztyn suggest that it was classless water of high turbidity (WIOŚ Olsztyn, 2009). There are no sewage discharge outfalls or other visible sources of pollutions. The water does not smell. Sporadically, some foaming on the surface of the river appeared during spring high water levels.

Trees growing within segments B, C and D, i.e. in the upper course of the river, create compact communities on both sides of the river and mainly belong to riparian forests, alder carr woods or their degraded forms; riparian thickets often overgrow river banks. Fewer trees grew only in the first of the analysed segments (segment A), which scored 4, and that was caused by a larger contribution of farmland. Farmland and shrubs made up $60 \%$ of the river banks along that segment.

The vegetation cover of the river banks corresponded to the type of the habitat, although the actual communities were often poor in species. In some places, a considerable share of nitrophilous species, especially nettle Urtica dioica, was observed. Rushes or their trace presence were recorded along the whole length of segments $A$, $C$ and D - everywhere they covered over $30 \%$ of the surface area within $1 \mathrm{~m}$ of the river banks, which scored these segments 5 points. The score was lower along segment $\mathrm{B}$ (score 3 ) because, due to the bank erosion, many landslides and high banks, rushes could not develop and covered only $20-25 \%$ of the segment length.
The whole analysed section of the river belongs to a Landscape Protection Area. Hence, the score for the parameter Outstanding Environmental Values was 3.

The results of the ecomorphological evaluation in the form of assigning the river a category of naturalness, for each segment, are given in table 3, The lowest value was assigned to segment A, which agrees with the subjective observations made during the field evaluation. The point score (3.50) is a value within category II, but is also a borderline value between categories II and III of naturalness. This is the part of the river where the highest contribution of agrocenoses was recorded, such as tilled fields, meadows and pastures. It was also there that the highest number of nitrophilous species was found and, among plant assemblages, ruderal communities were most common while the plant communities that were natural in this habitat were poor in species. The natural character of the river features more strongly downstream. Segment C scored the highest, which enabled us to classify it as belonging to category I. The last of the analysed segments (segment D) was also characterised by a high degree of naturalness (4.38), but it differed from segment $C$ in a larger share of forest plantations and considerable land depression.

The results of the RHS analyses showed some difference between RHS1 and RHS2. The Habitat Modification Score (HMS) for the former segment was 5, mainly due to the presence of a large bridge - but it still means an only slightly modified river section (Table 4). Along the latter segment (RHS2), no modifications to the watercourse were observed; therefore it is a natural section of the river (Table 4). The Habitat Quality Assess-

Table 3. Results of ecomorphological evaluation of the Łyna River for the section between Kortowo-Adrapy.

\begin{tabular}{|c|c|c|c|c|}
\hline Kilometer of the river & $0-2$ & $2.1-3.5$ & $3.6-5.2$ & $5.3-7.0$ \\
\hline Morphology of the channel & 4 & 5 & 5 & 5 \\
\hline Hydrology of the watercourse & 5 & 5 & 5 & 5 \\
\hline Water quality & 2 & 2 & 2 & 2 \\
\hline Trees along the river channel & 3 & 5 & 5 & 5 \\
\hline Water and river bank plants & 5 & 3 & 5 & 5 \\
\hline Land relief of the river shore zone & 3 & 4 & 5 & 4 \\
\hline Land-use in the river valley & 3 & 3 & 3 & 3 \\
\hline Environmental value & 3 & 30 & 4.38 & 34 \\
\hline Total score & 28 & 3.75 & I & 4.25 \\
\hline Mean score & 3.5 & II & & II \\
\hline
\end{tabular}


Table 4. The value of Habitat Modification Score (HMS) for two RHSs within the section between Kortowo-Adrapy.

\begin{tabular}{|c|c|c|}
\hline Calculation of HMS & RHS 1 & RHS 2 \\
\hline $\begin{array}{c}\text { 1. Modifications evaluated in profiles } \\
\text { 2. Modifications along the 500-m sec- } \\
\text { tion }\end{array}$ & 0 & 0 \\
\hline modifications of the channel & 0 & 0 \\
\hline modifications of the banks & 3 & 0 \\
\hline water engineering constructions & 1 & 0 \\
\hline general degree of modification & 1 & 0 \\
\hline Total: & 5 & 0 \\
\hline
\end{tabular}

Table 5. The value of Habitat Quality Assesment Score (HQA) for two RHSs within the section between Kortowo-Adrapy.

\begin{tabular}{|c|c|c|}
\hline Calculation of HQA & RHS 1 & RHS 2 \\
\hline 1. Physical attributes of the channel & & \\
\hline evaluated in profiles & 3 & 3 \\
\hline evaluated between profiles & 1 & 2 \\
\hline 2. Physical attributes of the banks & & \\
\hline Evaluated in profiles & 3 & 3 \\
\hline Evaluated between profiles & 6 & 8 \\
\hline Number of point bars & 1 & 1 \\
\hline 3. Structure of plants on banks & 9 & 11 \\
\hline 4. Types of plants in the channel & 5 & 6 \\
\hline 5. Land-use within 50 m of the channel & 7 & 14 \\
\hline 6. Trees & & \\
\hline continuity of tree communities & 5 & 6 \\
\hline presence of associated features & 10 & 12 \\
\hline 7. Other features proving natural \\
character & 5 & 5 \\
\hline Total: & 40 & 54 \\
\hline
\end{tabular}

ment Score (HQA) was also different for the two segments (Table 5). According to this score, habitats in RHS1 were more strongly modified.

It is not possible to evaluate the quality of the analysed section of the Eyna Rive based on the calculated RHS scores because there is no reference group of rivers ready for Poland. Another obstacle is that our study dealt with a mediumsize river whereas the RHS method is primarily designed for small rivers.
It has been assumed that the RHS database collected at the Chair of Ecology and Environment Conservation of the University of Agriculture in Poznan can approximately correspond to a reference group (Jusik 2005). Based on this assumption, it can be concluded that RHS1 belongs to category II or III (Table 6), while RHS2 should be classified as category II.

\section{Discussion}

The hydromorphological river quality components in the WFD have been classified into three groups: hydromorphological regime, river continuum and morphological conditions (Monitoring Guidance ... 2003).

When analysing each of the hydromorphological groups comprising water quality components, it can be concluded that in the quality evaluation performed with either of the methods the parameters of the river continuum and morphological conditions are most precisely characterised, while the hydrological regime attains the least precise description.

Both methods analyse water flows in real time. Historic flows are not taken into consideration in the RHS method while in the ecomorphological evaluation they are analysed during the stage of collecting available documentation as part of the preliminary work. Both methods supply, or can supply after small modifications, the data necessary for creating model flows. This step can be also performed as direct observations or in the form of existing materials based on an inventory of the existing documentation, produced for another purpose. This possibility, however, needs further elaboration.

The relationship between the analysed watercourse and some of the subsurface water in both methods is not a subject of this research. How-

Table 6. RHS evaluation of the Łyna River on the section between Kortowo-Adrapy considered by HMS and HQA.

\begin{tabular}{|l|c|c|c|c|c|c|}
\hline & & & \multicolumn{2}{|c|}{ HQA1=40; QA2=54 } & & \\
\hline & & Upper 20\% & Upper 40\% & $\mathbf{4 0 - 6 0 \%}$ & Lower 40\% & Lower 20\% \\
\hline HMS2=0 & Natural (HMS 0-2) & I & II & II & III & III \\
\hline HMS1=5 & Weakly modified (HMS 3-8) & II & II & III & III & IV \\
\hline & Moderately modified (HMS 9-20) & III & III & III & IV & IV \\
\hline & Considerably modified (HMS 21-44) & III & IV & IV & IV & V \\
\hline & Strongly modified (HMS $>$ 45) & IV & IV & V & V & V \\
\hline
\end{tabular}


ever, in the ecomorphological evaluation the materials collected during the preliminary stage can, for example, deal with the level of the groundwater table (such data are usually available). Each method takes into consideration the inflow of surface water.

The river continuum is well analysed in both methods.

Both methods enable very good analysis of morphological conditions. The ecomoprhological evaluation most often uses the term 'catchment'. In RHS, the measurement points are set up a priori, at precisely established transects of a watercourse.

In the ecomorphological evaluation method, questions are raised by the ecological evaluation of water plants or plants growing on watercourse banks. The term 'water plants' is reserved for associations of the class Potamogetonetea, i.e. plants with floating leaves or submerged plants. These communities are often poor in species, therefore the statement 'the species composition of water plant associations close to the natural one (over 5 species)' (Ilnicki \& Lewandowski 1997) is questionable. The species composition of water plants growing in lotic water very rarely exceeds 5 species and sometimes these are single-species phytocenoses (Tomaszewicz 1979). It would be more appropriate to refer to the number of water plant species along the whole analysed section of a river rather than the number of species creating recorded plant communities. Therefore, in our paper water plants were excluded from this criterion. We only included a description of rushes. We would suggest that this criterion be revised with respect to water plants.

In the RHS method, the list of non-native species (the so-called expansive neophytes) does not correspond to the Polish flora. In the ecomorphological evaluation, the question of foreign species is not raised.

In RHS, the question of river bank vegetation is a physiognomic issue. Moreover, the description of water plants and rushes is ambiguous and doubts are raised by the terms: emergent narrowleaved and emergent broad-leaved or submerged fine-leaved and submerged broad-leaved plants. Especially the group called 'emergent' should be revised.
RHS does not refer to forms of nature conservation imposed by the law to protect the analysed watercourse. It does not include any information on nature reserves or other specific forms of nature conservation present in the analysed area. In the ecomorphological evaluation method, it is one of the evaluation criteria.

The ecomorphological evaluation is somewhat inconsistent in that it uses criteria of river water quality assessment based on results of physicochemical monitoring. It is a useful criterion but is broader than the requirements imposed by the WFD.

Noteworthy is the fact that the implementation of RHS, mainly in the UK (Fox et al. 1998) but also in Poland (Szoszkiewicz et al. 2005), includes an advanced process of control and verification.

\section{Conclusions}

Both methods proved that as we moved downstream, the ecological value of the Eyna River rose; the results are shown in the form of mental maps. The ecomorphological evaluation of watercourses according to Ilnicki assesses a river along its whole length, which is in accord with the assumptions of the WFD. The evaluation with RHS along selected 500-meter sections of a river means that it lacks continuity. The evaluation with the RHS method in the present case meant that the most valuable section of the river was excluded.

The RHS method (owing to the HQA) is more efficient in assessing the man-made pressure on the river. No such precise criterion can be found in the ecomorphological evaluation method. In the ecomorphological evaluation according to Ilnicki, determination of the degree of naturalness or extent of man-made modifications is more subjective and therefore requires an experienced surveyor. RHS is unambiguous and objective but needs to be adjusted to the Polish conditions. Both methods can undergo statistical processing. At present, it is difficult to compare the reliability of the results obtained by both methods. RHS needs a reference group of rivers, which does not exist in Poland. Assuming that the RHS database prepared for the watercourses analysed at the 
University of Agriculture in Poznań is close to such a reference groups of rivers in Poland, it can be said that the results produced by both methods in the present study are similar.

Most watercourses in Poland have rich cartographic documentation as well as many descriptive texts on their geomorphology, physiography, geology, hydrography, soils and topography, etc. The methodological basis of RHS does not presume that the existing references on the analysed watercourses be used, unlike the ecomorphlogical evaluation, which includes the preliminary stage, when it is recommended to gather and analyse such available reference material.

\section{References}

Agences de l'Eau and Ministère de l'Environnement, 1998. SEQ-Physique: a System for the Evaluation of the Physical Quality of Watercourses.

Anderson J.R., 1993. State of the Rivers Project. Report 1. Development and Validation of the Methodology. Department of Primary Industries, Queensland.

Bєachuta J., CZoch K., Kulesza K. \& Picińska-FaŁtynowicz J., 2005. Typologia rzek i strumieni Polski. Ecostatus. Ogólnopolska Konferencja „Wdrażanie Ramowej Dyrektywy Wodnej. Ocena stanu ekologicznego wód w Polsce". Łódź.

Directive 2000/60/EC of the European Parliament and of the Council of 23 October 2000 establishing a framework for Community action in the field of water policy, 2000. Official Journal L 327, 22/12/20000 P. Document 300L0060.

Environment Agency, 2003. River Habitat Survey in Britain and Ireland: Field Survey Guidance Manual. River Habitat Survey Manual: 2003 version. Environment Agency.

FALIŃSKI J.B., 1990. Kartografia geobotaniczna. Państwowe Przedsiębiorstwo Wydawnictw Kartograficznych im. Eugeniusza Romera. Warszawa-Wrocław.

Fox P.J.A., Naura M. \& Scarlett P., 1998. An account of the derivation and testing of a standard field method, River Habitat Survey. Aquatic Conservation: Marine and Freshwater Ecosystems, 8: 455-475.

Grzybowski M., WiśNIEWSKi K. \& Kleinschmidt L., 2005. Ocena oddziatywania zbiornika przy elektrowni wodnej na Łynie w Ardapach na ożywione środowisko przyrodnicze wykonana na etapie projektu budowlanego. Pracownia Projektowa Budownictwa Wodnego, Olsztyn..

ILlies J. (ed.), 1978. Limnofauna Europeae. 2. Überarbeitete und ergänzte Auflage. G. Fischer Verlag, Stuttgart, New York.

ILNICKI P. \& GóRECKI K., 2005. Metody hydromorfologicznej waloryzacji rzek stosowane dotychczas w krajach Unii Europejskiej. Ecostatus. Ogólnopolska Konferencja „Wdrażanie Ramowej Dyrektywy Wodnej. Ocena stanu ekologicznego wód w Polsce". Łódź.

ILNICKI P. \& LEWANDOWSKI P., 1997. Ekomorfologiczna waloryzacja dróg wodnych Wielkopolski. Bogucki Wyd. Nauk., Poznań.
ILnicki P., GoŁdyn R., Soszka H., GóRecki K., GrZYbowski M., Krzemińska A., Lewandowski P., Skocki K., Sojka M. \& MarcinKIeWicz M., 2009a. Opracowanie metodyk monitoringu i klasyfikacji hydromorfologicznych elementów jakości jednolitych części wód rzecznych i jeziornych, zgodnie $z$ wymogami Ramowej Dyrektywy Wodnej. ETAP II. Zadanie 2 i 3. Kod CPV: 9071 1500-9. Nomenklatura wg CPV: 90711500-9. Poznań listopad 2009 roku GEPOL sp. z o.o., Poznań.

Ilnicki P., GoŁdyn R., Murat-BŁażejewska S., Soszka H., GóReCKI K., Grzybowski M., KrzemińsKa A., LeWANDOWSKI P., SKocki K., Bedry M., Cichy W. \& MarcinKiewicz M., 2009b. Opracowanie metodyk monitoringu i klasyfikacji hydromorfologicznych elementów jakości jednolitych części wód rzecznych i jeziornych, zgodnie z wymogami Ramowej Dyrektywy Wodnej. ETAP I. Zadanie 1. Kod CPV: 9071 1500-9. Nomenklatura wg CPV: 90711500-9. Poznań 15 luty 2009 roku. GEPOL sp. z o.o., Poznań.

Ilnicki R., Górecki K., Grzybowski M., KrZemińsKa A., LeWANDOWSKI R. \& SOJKA M., 2010a. Principles of hydromorphological surveys of Polish rivers. J. Water Land Dev.: 143-13.

ILNicki R., GóreCKi K., Grzybowski M., KrZemińSKa A., LeWANDOWSKI R. \& SOJKA M., 2010. Ecological quality classes of river hydromorphology in Poland. J. Water Land Dev.: $15-27$.

JusIK Sz., 2005. Hydromorfologiczne wskaźniki syntetyczne: Habitat Quality Assessment (HQA) i Habitat Modification Score (HMS). Cz. 3. In: Zastosowanie metod hydromorfologicznych w ocenie stanu ekologicznego rzek. AR Poznań, Poznań: 1-15 (mscr).

KondRACKI J., 2002. Geografia regionalna Polski. PWN, Warszawa.

MatuszKiewicz J.M., 1993. Krajobrazy roślinne i regiony geobotaniczne Polski. Prace Geogr. 158: 5-107.

Matuszkiewicz J.M., 2001. Zespoły leśne Polski. Wyd. Naukowe PWN. Warszawa. pp. 358

MatuszKIEWICZ W., 1974. Teoretyczno-metodyczne podstawy badań roślinności jako elementu krajobrazu i obiektu użytkowania rekreacyjnego. Wiadomości Ekologiczne 20(1): 3-13.

Milner N.J., Wyatt R.J. \& Broad K., 1998. HABSCORE - applications and future developments of related habitat models. Aquatic Conservation: Marine and Freshwater Ecosystems, 8(4): 633-644.

Monitoring Guidance on Monitoring for the Water Framework Directive. Final Version 23 January 2003, Water Framework Directive Common Implementation Strategy Working Group 2.7.

Norris R.H., Prosser I., Young B., Liston P., Bauer N., Davies N., Dyer F., Linke S. \& Thoms M., 2001. The Assessment of River Condition. An Audit of the Ecological Condition of Australian Rivers. Final Report submitted to the National Land and Water Resources. Audit.

Parsons M., Thoms M. \& Norris R., 2002. Australian River Assessment System: Review of Physical River Assessment Methods - A Biological Perspective. Cooperative Research Centre for Freshwater Ecology, Monitoring River Health Initiative Technical Report Number 21. Environment Australia

Raven P.J., Boon P.J., Dawson F.H. \& Ferguson A.J.D., 1998. Towards an integrated approach to classifying and evaluating rivers in the UK. Aquatic Conservation: Marine and Freshwater Ecosystems, 8: 383-393. 
Rozporzązenie Ministra Środowiska z dnia 28 września 2004 r. w sprawie gatunków dziko występujących zwierząt objętych ochrona (Dz.U. z dnia 28 września 2004 r. nr 220, poz. 2237).

Rozporzadzenie Ministra Ochrony Środowiska, Zasobów Naturalnych i Leśnictwa $z$ dnia 9 lipca 2004 r. w sprawie ochrony gatunkowej roślin (Dz.U. z dnia 28 lipca 2004 r., nr 168, poz. 1764).

Rozporządzenie Wojewody Warmińsko-Mazurskiego nr 21 z dnia 14 kwietnia 2003 r. w sprawie wprowadzenia obszarów chronionego krajobrazu na terenie województwa warmińskomazurskiego (Olsztyn, dnia 22 kwietnia 2003 r.), Warmi.03.52.725.

Szoszkiewicz K.J, Staniszewski R., Jusik Sz. \& ZgoŁa T., 2005. Możliwości wykorzystania systemu River Habitat Survey w ocenie hydromorfologicznej rzek na potrzeby Ramowej Dyrektywy Wodnej. Ecostatus. Ogólnopolska Konferencja
„Wdrażanie Ramowej Dyrektywy Wodnej. Ocena stanu ekologicznego wód w Polsce". Łódź: 42-43.

Terlecki J., Kozłowski J., Dostatni D., Hliwa P., Józsa V., MarTYNIAK A., PrZYbylski M. \& WZiĄTeK B., 2004. Ichtiofauna rzeki Łyny oraz Gubra, Dajny i Sajny. Roczniki Naukowe PZW, 17: 35-54.

Tomaszewicz H., 1979. Roślinność wodna i szuwarowa Polski. Rozprawy UW, Warszawa.

WIOŚ Olsztyn, 2009. Badania monitoringowe wód powierzchniowych na terenie województwa warmińsko-mazurskiego w 2008 r. (http:/ / www.pios.gov.pl/olsztyn/wodypow/ wodypow04.html).

Zarzycki K., Wojewoda H. \& HeinRich Z., 1992. Lista roślin zagrożonych w Polsce. Instytut Botaniki im. W. Szafera. Polska Akademia Nauk., Kraków. 